\title{
LIST OF MAPS
}

1: Anglo-French peace conferences during the reign of Henry II $\quad 26$

2: Peace conferences during the reign of Richard I 34

3: Anglo-Welsh conferences 1154-1216 48

4: Anglo-Scottish conferences 1154-1199 54

5: Anglo-Scottish conferences 1199-1216 55 